\title{
RESEARCH NOTE \\ Effect of Unconventional Oils on in Vitro Rumen Methane Production and Fermentation
}

\author{
Mohamed G. Embaby ${ }^{1}$, Mevlüt Günal ${ }^{2}$, and Amer AbuGhazaleh ${ }^{1}$ \\ ${ }^{1}$ Southern Illinois University, Department of Animal Science, Food and Nutrition. Carbondale, IL 62901, \\ USA. \\ ${ }^{2}$ Isparta University of Applied Sciences, Department of Animal Science. Isparta 32260, Turkey.
}

\begin{abstract}
M. Embaby, M. Günal, and A. AbuGhazaleh. 2019. Effect of unconventional oils on in vitro rumen methane production and fermentation. Cien. Inv. Agr. 46(3): 276-285. The effects of unconventional oils high in polyunsaturated fatty acids (PUFAs) (blackberry, blueberry, raspberry, pomegranate, black seed and hemp oils) on in vitro rumen fermentation and methane $\left(\mathrm{CH}_{4}\right)$ production were examined in a 24-h batch culture experiment. Treatments consisted of a control (no oil supplement), a control plus corn oil, or a control plus the unconventional oils. Oils were added to rumen cultures at $500 \mathrm{mg} \mathrm{L}^{-1}$ (equivalent to $3.3 \mathrm{~g}$ oil. $\mathrm{kg}^{-1}$ of dietary dry matter (DM)). After $24 \mathrm{~h}$ of incubation, $\mathrm{CH}_{4}$ production was not different between the control and the corn oil treatment. Of the six unconventional oils tested, only the hemp and blueberry oils reduced $\mathrm{CH}_{4}$ production by $10-16 \%$ relative to that of the control and corn oil treatments. Dry matter degradability and total volatile fatty acids (VFAs) were not affected by the addition of oils. Except for a reduction in the acetate concentration with the raspberry and hemp oils, all tested unconventional oils had no effects on fermentation and the VFA profile relative to those of the control. In conclusion, our results showed that hemp and blueberry oils were moderately effective in reducing rumen $\mathrm{CH}_{4}$ formation without compromising rumen fermentation and digestibility.
\end{abstract}

Keywords: Blueberry oil, hemp oil, methane, raspberry oil, rumen culture.

\section{Introduction}

The microbial fermentation of feeds consumed by ruminant animals produces methane $\left(\mathrm{CH}_{4}\right)$ as a byproduct. Although methanogenesis prevents adverse effects of hydrogen accumulation in the rumen, $\mathrm{CH}_{4}$ production has a detrimental effect

Received Jan 09, 2019. Accepted Jul 30, 2019.

Corresponding author: aabugha@siu.edu on the atmosphere and represents a loss of feed energy from the diet. Different mitigation strategies to reduce $\mathrm{CH}_{4}$ emissions from ruminants, either as a direct effect on the methanogenic bacteria or an indirect effect through inhibiting microorganism interaction with methanogenic bacteria, has been examined (Beauchemin et al., 2008). Dietary lipid supplementation was reported to reduce $\mathrm{CH}_{4}$ production in rumens by reducing rumen ciliated protozoa (Ivan et 
al., 2013), reducing the activity of methanogens, or through the use of hydrogen during the biohydrogenation process (Chilliard et al., 2009). However, when lipid supplements were added at levels greater than $4 \%$ of the dietary dry matter (DM), the reductions in rumen $\mathrm{CH}_{4}$ production were also associated with reductions in substrate fermentation and digestibility (Whitney et al., 2000; Wang et al., 2017).

As a result of their anti-microbial properties that could affect methanogenic bacteria or protozoa in the rumen, phenolic compounds, such as flavonoids, are one of the most popular plant extracts that have attracted the interest of researchers to reduce $\mathrm{CH}_{4}$ emissions (GarciaGonzalez et al., 2008; Oskoueian et al., 2013). Pomegranate, black seed, hemp and berry oils are characterized by their high polyunsaturated fatty acid (PUFA) content. The seeds of these oils are also rich in polyphenolic compounds, such as proanthocyanidins, hydrolyzable tannins, and flavonols, that have potent antioxidant and antimicrobial properties (McPartland, 1984; Dahham et al., 2010). During cold processing, these compounds are extracted into cold pressed oil in significant quantities (Parry and $\mathrm{Yu}, 2004)$. Although plant oils high in PUFAs, such as rapeseed, sunflower, soybean, corn and linseed oils, have been intensively studied for their potential to reduce $\mathrm{CH}_{4}$ production (Machmüller et al., 1998; Lillis et al., 2011; Ivan et al., 2013), unconventional oils high in PUFAs and rich in phenolic compounds have not yet been investigated for their efficiency in mitigating rumen $\mathrm{CH}_{4}$ production. Therefore, the main objective of this study was to investigate the effects of blackberry, blueberry, raspberry, pomegranate, black seed and hemp oils on rumen $\mathrm{CH}_{4}$ production and fermentation in-vitro.

\section{Materials and Methods}

This study was approved by the Ethical Committee of the Institutional Animal Care and Use Committee-Southern Illinois University Carbondale, with a tracking number of $18-025$.

\section{Oil sources}

The six unconventional oils used in our experiment were blackberry (Rubus fruticosus) seed oil, blueberry (Vaccinium corymbosum) seed oil, raspberry (Rubus idaeus) seed oil, pomegranate (Punica granatum) seed oil, black seed (Nigella sativa) oil, and hemp (Cannabis sativa) seed oil. Oils were acquired from NOW Foods Essential Oil Company (Bloomingdale, IL, USA), Nutiva (Richmond, CA, USA), and Puressant (Missouri city, TX, USA). All oils were unrefined and cold-pressed.

Experimental design, in vitro incubation procedure and laboratory analysis

Rumen fluid was collected $3 \mathrm{~h}$ after morning feeding from a lactating cannulated Holstein cow fed a total mixed ration consisting of alfalfa and grass hay mix $\left(600 \mathrm{~g} \mathrm{~kg}^{-1}\right)$, ground corn $(250 \mathrm{~g}$ $\left.\mathrm{kg}^{-1}\right)$, soy hulls $\left(100 \mathrm{~g} \mathrm{~kg}^{-1}\right)$, and soybean meal (50 $\mathrm{g}$ $\mathrm{kg}^{-1}$; all on a DM basis). The rumen contents were strained through two layers of cheesecloth (1 mm pore size) and then used within approximately 15 min after collection. Twelve ANKOM gas jars (3 per treatment) containing finely ground $(1 \mathrm{~mm}$ screen) diet (3 g), strained ruminal fluid $(70 \mathrm{ml})$ and preheated buffer media $(130 \mathrm{ml})$ were used as batch rumen cultures. The buffer was prepared according to Goering and Van Soest (1970). The diet consisted of (on a DM basis) alfalfa hay (250 $\left.\mathrm{g} \mathrm{kg}^{-1}\right)$, corn silage (250 $\left.\mathrm{g} \mathrm{kg}^{-1}\right)$, ground corn (300 $\left.\mathrm{g} \mathrm{kg}^{-1}\right)$, soybean meal $\left(100 \mathrm{~g} \mathrm{~kg}^{-1}\right)$, soy hulls $(80$ $\left.\mathrm{g} \mathrm{kg}^{-1}\right)$, and a mineral-vitamin mix $\left(20 \mathrm{~g} \mathrm{~kg}^{-1}\right)$. Treatments were a control (no lipid supplement), a control plus corn oil, and a control plus each of the six unconventional oils (pomegranate oil, raspberry oil, blackberry oil, blueberry oil, black seed oil or hemp oil). Oil supplements were added 
to jars at a rate of $500 \mathrm{mg} \mathrm{L}^{-1}$ of rumen culture (amounts equivalent to $3.3 \mathrm{~g} \mathrm{~g} \mathrm{~kg}^{-1}$ of dietary DM), and treatments were run in triplicate. To estimate the effects of treatment diets on DM degradability, approximately 1.5 grams of ground Timothy hay (1 mm screen) weighed into a Dacron bag (5-cm $\times 10$-cm bags with a $20-\mu \mathrm{m}$ pore size; Ankom Inc., Fairport, NY, USA) and placed in each of the ANKOM jars. After $24 \mathrm{~h}$ of incubation, the bags were removed and rinsed in cold water for a total of six rinses. The bags were then dried in an oven at $55^{\circ} \mathrm{C}$ for $48 \mathrm{~h}$, placed in a desiccator for $3 \mathrm{~h}$, and weighed. The samplers and diets were then analyzed for DM (AOAC, 2000).

Each jar was gassed with carbon dioxide $\left(\mathrm{CO}_{2}\right)$ before sealing and then connected to a Tedlar gas collection bag (CEL Scientific Corp., Santa Fe Springs, CA, USA). Jars were placed in a water bath at $39{ }^{\circ} \mathrm{C}$ for $24 \mathrm{~h}$. Gasses from jars were programmed to be released into connected bags when the psi exceeded 1.0. Every two hours, the jars were shaken by hand for approximately 30 seconds. After $24 \mathrm{~h}$, gas bags were disconnected from jars and analyzed immediately for gas composition. From each collected gas bag, three separate gas samples were collected using a 1-ml gas tight needle syringe (27G $11.4^{-1}$; Fisher Scientific, Chicago, IL, USA) and analyzed for gas composition using a gas chromatograph (SRI 8610C, Torrance, CA, USA) equipped with a TCD detector $(6 " \times 0.125$ " S.S. Shin Carbon) and an ST 80/800 column $(2 \mathrm{~m} \times 2 \mathrm{~mm}$ ID). The oven temperature was programmed at $38^{\circ} \mathrm{C}$ for five min, then increased at $5{ }^{\circ} \mathrm{C} \cdot \mathrm{min}^{-1}$ to $270{ }^{\circ} \mathrm{C}$ and held for five min. The carrier gas was argon. Sample gas peaks $\left(\mathrm{CO}_{2}\right.$ and $\left.\mathrm{CH}_{4}\right)$ were identified by comparing the retention times with those of the corresponding standard (Scotty Analyzed Gases 14, Sigma-Aldrich, St. Louis, MO, USA).

The relative proportion of each gas in the collected gas bags was calculated using the response factor (RF) equation:

$$
\mathrm{RF}=\left(\mathrm{CC}_{i} \cdot \text { Area }_{i}^{-1}\right) \times\left(\text { Area }_{r e f} \cdot \mathrm{CC}_{r e f}^{-1}\right)
$$

where $\mathrm{RF}$ is the response factor, $\mathrm{CC}_{i}$ is the proportion of gas $i$ in the sample of the gas being tested, Area $_{i}$ is the area of the gas $i$ peak, $\mathrm{CC}_{\text {ref }}$ is the proportion of the reference gas (helium) in the internal standard, and Area ${ }_{\text {ref }}$ is the area of the peak of the reference gas.

To calculate the relative proportion of each gas in the collected gas bags, Avogadro's Law was used:

$$
\mathrm{N}=\mathrm{P}\left(\mathrm{V} \cdot \mathrm{RT}^{-1}\right)
$$

Where $\mathrm{N}$ is the amount of gas produced in moles, $\mathrm{P}$ is the pressure in kilopascals, $\mathrm{V}$ is the headspace volume in the gas jars in liters, $\mathrm{T}$ is the temperature in Kelvins, and $\mathrm{R}$ is the gas constant.

At the end of each experiment, two $5 \mathrm{~mL}$ samples were also collected from each culture jar for VFA and ammonia- $\mathrm{N}\left(\mathrm{NH}_{3}-\mathrm{N}\right)$ determination. Collected samples were placed immediately in an ice bath and then stored at $-20^{\circ} \mathrm{C}$ until analyses. The $\mathrm{pH}$ was measured immediately after samples were collected from each jar with a portable $\mathrm{pH}$ meter. Samples for VFA analysis were mixed with $1 \mathrm{~mL}$ of freshly prepared $25 \%$ meta-phosphoric acid and centrifuged (IEC Centra GP8R, Needham Heights, MA, USA) at $20,000 \mathrm{~g}$ and $4{ }^{\circ} \mathrm{C}$ for 20 $\mathrm{min}$. The supernatant fluid was then collected and analyzed for VFAs using 2-ethylbutyric acid as an internal standard (Jenkins, 1987). A Shimadzu GC-2010 gas chromatograph (Shimadzu Scientific Instruments Inc., Columbia, MD, USA) equipped with a flame-ionization detector and a $30-\mathrm{m}$ SP-2560 fused silica capillary column (Restek Stabil WAX DA column, Bellefonte, PA, USA) was utilized for VFA analysis. The helium carrier gas was maintained at a linear velocity of $23 \mathrm{~cm}$ $\mathrm{s}^{-1}$. The oven temperature was programmed to $65^{\circ} \mathrm{C}$ for $3 \mathrm{~min}$ and increased at $12{ }^{\circ} \mathrm{C} \mathrm{min}-1$ to a final temperature of $225^{\circ} \mathrm{C}$, which was held for 9 min. The column temperature was maintained at $65^{\circ} \mathrm{C}$, and the flame ionization detector temperature was maintained at $225^{\circ} \mathrm{C}$. For ammonia-N, the $5 \mathrm{~mL}$ collected sample was centrifuged at 20,000 $\mathrm{g}$ and $4{ }^{\circ} \mathrm{C}$ for $10 \mathrm{~min}$. The supernatant 
was then acidified with $0.5 \mathrm{~mL}$ of $0.1 \mathrm{~N} \mathrm{HCl}$ and analyzed for ammonia-N, as outlined by Cotta and Russell (1982).

Data were analyzed using the MIXED procedures of SAS (Version 9.1, Statistical Analysis System 2003) using treatment as the fixed effect and replicate as the random effect. Differences among treatment means were tested using PDIFF. All results were expressed as least-square means, and significance was declared at $P<0.05$.

\section{Results}

The fatty acid composition for the tested oils is presented in Table 1. Polyunsaturated fatty acids were the dominant fatty acids in all oils, ranging from $65 \%$ to $80 \%$ of total fatty acids. The highest PUFA levels were in hemp and raspberry oils, and the lowest PUFA levels were in corn oil. Except for pomegranate oil, linoleic acid (C18:2 $c 9 c 12)$ was the main PUFA in all oils, ranging from $44.7 \%$ to $64 \%$ of total fatty acids. Linolenic acid (C18:3 $c 9 c 12 c 13)$ was highest in blueberry oil at approximately $32 \%$. In pomegranate oil, punicic acid (C18:3 $c 9 t 11 c 13)$ was the main fatty acid at $61 \%$ of total fatty acids.

The effects of oils on rumen fermentation and $\mathrm{CH}_{4}$ production are presented in Table 2 and Figure 1. Relative to the control and corn oil treatments, only the addition of blueberry oil and hemp seed oil reduced $(P<0.05) \mathrm{CH}_{4}$ pro- duction, while blackberry oil tended to decrease $(P>0.12) \mathrm{CH}_{4}$ production. The DM degradability, total VFAs, propionate, butyrate and $\mathrm{NH}_{3}-\mathrm{N}$ concentrations were all similar $(P>0.05)$ across treatments. Relative to that of the control, total gas production decreased $(P<0.05)$ only with the addition of corn oil and black seed oil. The acetate concentration was lower $(P<0.05)$ in the raspberry oil and hemp oil treatments relative to that of the control.

\section{Discussion}

Previous studies reported linear reductions in rumen $\mathrm{CH}_{4}$ production with the addition of lipid supplements. However, at dietary lipid supplements greater than $4 \%$ of dietary DM, the reduction in $\mathrm{CH}_{4}$ was confounded with a decrease in DM degradability (Whitney et al., 2000; Wang et al., 2017). Therefore, oils in our experiments were added at levels that are reported to have minimum effects on substrate fermentation and digestibility. The addition of corn oil and the unconventional oils to rumen cultures in our experiments had no effects on DM degradability and total VFAs compared with those of the control, suggesting that these oils had no negative effects on rumen fermentation. These effects are consistent with the findings of others who reported little or no effects of oils on fermentation when added at lower levels (Patra, 2013; El-Sherbiny et al., 2016; Roy et al., 2017).

Table 1. Fatty acid composition for oil supplements ( $\mathrm{g} 100 \mathrm{~g}$ fatty $\left.\mathrm{acid}^{-1}\right)$.

\begin{tabular}{lccccccc}
\hline & $\mathrm{C} 16: 0$ & $\mathrm{C} 18: 0$ & $\mathrm{C} 18: 1 \mathrm{c} 9$ & $\mathrm{C} 18: 2 \mathrm{c} 9 \mathrm{c} 12$ & $\mathrm{C} 18: 3 \mathrm{c} 9 \mathrm{c} 12 \mathrm{c} 15$ & $\mathrm{C} 18: 3 \mathrm{c} 9 \mathrm{t} 1 \mathrm{c} 13$ & PUFA \\
\hline Corn oil & 7.53 & 0.58 & 26.31 & 64.00 & 0.85 & 0.00 & 64.85 \\
Blackberry oil & 7.71 & 2.29 & 20.40 & 59.00 & 9.70 & 0.00 & 68.70 \\
Blueberry oil & 2.63 & 0.52 & 18.74 & 44.73 & 32.15 & 0.00 & 76.88 \\
Black seed oil & 7.71 & 1.55 & 22.62 & 63.71 & 0.24 & 0.00 & 63.95 \\
Hemp oil & 3.22 & 1.03 & 7.08 & 60.20 & 19.38 & 0.00 & 79.58 \\
Raspberry oil & 2.11 & 1.05 & 16.98 & 60.46 & 18.54 & 0.00 & 79.00 \\
Pomegranate oil & 5.79 & 1.95 & 15.60 & 3.83 & 7.09 & 61.28 & 72.20 \\
\hline
\end{tabular}

PUFA $=$ Polyunsaturated fatty acid 
Table 2. Effect of oil supplements on dry mater degradability and fermentation.

\begin{tabular}{|c|c|c|c|c|c|c|c|c|c|}
\hline & Control & Corn oil & $\begin{array}{c}\text { Pomegranate } \\
\text { oil }\end{array}$ & $\begin{array}{c}\text { Raspberry } \\
\text { oil }\end{array}$ & $\begin{array}{c}\text { Blackberry } \\
\text { oil }\end{array}$ & $\begin{array}{c}\text { Blueberry } \\
\text { oil }\end{array}$ & $\begin{array}{c}\text { Black seed } \\
\text { oil }\end{array}$ & $\begin{array}{l}\text { Hemp } \\
\text { oil }\end{array}$ & SEM \\
\hline $\begin{array}{l}\text { Dry matter } \\
\text { degradability, \% }\end{array}$ & 29.95 & 28.79 & 32.74 & 31.59 & 31.03 & 30.69 & 29.46 & 28.83 & 0.767 \\
\hline $\mathrm{pH}$ & 6.15 & 6.16 & 6.18 & 6.09 & 6.18 & 6.11 & 6.19 & 6.06 & 0.12 \\
\hline $\begin{array}{l}\text { Gas production, } \\
\mathrm{ml}\end{array}$ & $158.72^{\mathrm{a}}$ & $140.75^{\mathrm{b}}$ & $145.04^{\mathrm{ab}}$ & $147.95^{\mathrm{ab}}$ & $146.23^{\mathrm{ab}}$ & $148.26^{\mathrm{ab}}$ & $135.52^{\mathrm{b}}$ & $147.62^{\mathrm{ab}}$ & 4.604 \\
\hline $\mathrm{NH}_{3}-\mathrm{N}, \mathrm{mg} \cdot \mathrm{dL}^{-1}$ & 5.81 & 6.92 & 6.43 & 6.19 & 6.44 & 7.93 & 6.14 & 7.96 & 0.84 \\
\hline VFA total, $\mathrm{m} M$ & 42.15 & 41.86 & 42.54 & 38.27 & 43.14 & 39.26 & 38.83 & 37.36 & 2.698 \\
\hline Acetate $(\mathrm{C} 2)$ & $17.81^{\mathrm{a}}$ & $16.65^{\mathrm{ab}}$ & $17.36^{\mathrm{a}}$ & $15.26^{\mathrm{b}}$ & $18.05^{\mathrm{a}}$ & $16.12^{\mathrm{ab}}$ & $16.47^{\mathrm{ab}}$ & $14.97^{\mathrm{b}}$ & 1.037 \\
\hline Propionate(C3) & 12.18 & 12.03 & 12.25 & 11.13 & 13.76 & 12.1 & 11.49 & 10.93 & 0.859 \\
\hline Butyrate (C4) & 9.7 & 10.03 & 10.4 & 9.56 & 10.63 & 9.09 & 9.04 & 9.16 & 0.56 \\
\hline Iso-butyrate & $0.37^{\mathrm{a}}$ & $0.31^{\mathrm{a}}$ & $0.35^{\mathrm{a}}$ & $0.33^{\mathrm{a}}$ & $0.29^{\mathrm{a}}$ & $0.29^{\mathrm{a}}$ & $0.21^{\mathrm{b}}$ & $0.21^{\mathrm{b}}$ & 0.031 \\
\hline Valerate & 1.2 & 1.26 & 1.32 & 1.27 & 1.31 & 1.14 & 1.18 & 1.15 & 0.056 \\
\hline Iso-valerate & 0.88 & 0.9 & 0.85 & 0.83 & 0.47 & 0.42 & 0.76 & 0.76 & 0.096 \\
\hline $\mathrm{C} 2: \mathrm{C} 3$ & $1.54^{\mathrm{a}}$ & $1.52^{\mathrm{a}}$ & $1.42^{\mathrm{ab}}$ & $1.40^{\mathrm{b}}$ & $1.35^{\mathrm{b}}$ & $1.33^{\mathrm{b}}$ & $1.43^{\mathrm{ab}}$ & $1.37^{\mathrm{b}}$ & 0.033 \\
\hline
\end{tabular}

${ }^{\text {ab }}$ Values within rows followed by the same letter are not significantly different at $P<0.05$

VFAs $=$ volatile fatty acids; $\mathrm{NH} 3-\mathrm{N}=$ ammonia nitrogen; $\mathrm{SEM}=$ standard error of the mean

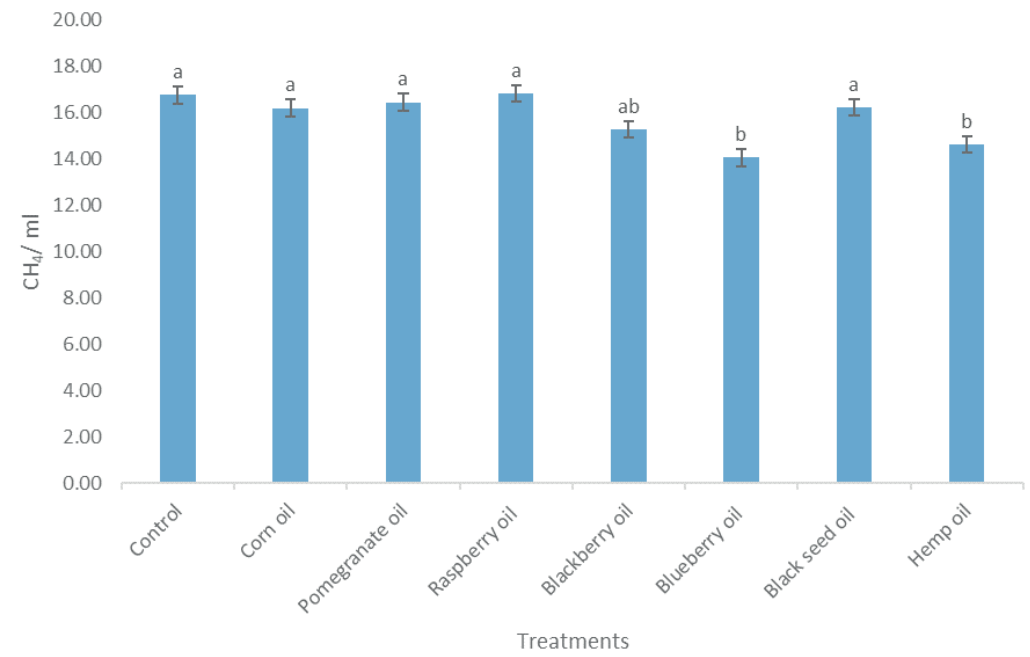

Figure 1. Effect of oil supplements on methane $\left(\mathrm{CH}_{4}\right)$ production.

${ }^{a b}$ the same letters are not significantly different at $\mathrm{P}<0.05$.

The rumen fermentation parameters, total VFA concentration and profile and $\mathrm{NH}_{3}-\mathrm{N}$ in our experiments were also not significantly affected by the addition of oils, suggesting again that the tested oils had minimum effects on rumen microbial fermentation. A decline in acetate production is usually associated with reductions in fiber digest- ibility, and in the current experiment, the acetate concentration decreased only with the addition of raspberry oil and hemp oil. Although previous studies (Lillis et al., 2011; Ivan et al., 2013) showed that unsaturated fatty acids had adverse effects on fibrolytic bacteria, it is unlikely that fatty acids had an effect in this experiment, as all 
oils had almost similar total unsaturated fatty acid contents. It is possible that raspberry oil and hemp oil had other components (e.g., flavonoids) that may have negatively affected fibrolytic bacteria. In the present study, the unchanged propionate concentration with the tested oils suggested that these oils had no or little effect on the degradation of other carbohydrates, such as starch. Salem et al. (1993) and Hervas et al. (2008) also observed that oil supplementation resulted in no variation in rumen amylolytic activity.

Supplementary oils can inhibit $\mathrm{CH}_{4}$ emission by reducing the activity/number of rumen methanogens and protozoa (Lillis et al., 2011), decreasing the amount of fermentable substrate, and/or through the biohydrogenation of unsaturated fatty acids (Chilliard et al., 2009). However, the biohydrogenation of unsaturated fatty acids is not quantitatively relevant and has a low potential of $\mathrm{CH}_{4}$ reduction compared to the decreased microbial activity and reduction of fermentable substrate (Ramin and Huhtanen, 2013). In the present study, the reduction in $\mathrm{CH}_{4}$ production with the blueberry and hemp oil diets may not be attributed to the reductions in substrate fermentation, as the DM degradability and total VFA with these two oils were not different from the other diets. The blueberry and hemp oil effects on $\mathrm{CH}_{4}$ production therefore most likely resulted from adverse effects on the rumen methanogens rather than decreasing substrate fermentation. The unsaturated fatty acids can directly inhibit rumen methanogenic archaea and may change their metabolic activity, as well as the composition of the rumen methanogenic population. Prins et al. (1972) observed that the growth of Methanobacterium ruminantium was severely inhibited in a pure culture by long-chain fatty acids. Popova et al. (2011) reported that the metabolic activity of methanogens in bulls decreased with the feeding of extruded linseed. Czerkawski et al. (1966) observed that the extent of in the suppression of $\mathrm{CH}_{4}$ production with supplementation of fatty acids is far greater than that of the suppression of fiber digestibility in sheep. Zhang et al. (2008) observed that Archaea populations were decreased only by linoleic and linolenic acids among stearic, oleic, linoleic and linolenic acids. In the current study, the fatty acid profile for the tested oils may explain in part the differences between oils regarding their effects on $\mathrm{CH}_{4}$ production. For example, the linolenic acid-to-linoleic acid ratio was greater in blueberry oil than in corn and blackberry oils. A meta-analysis study by Patra (2013) reported that linolenic acid had more inhibitory effects on methanogenesis than linoleic acid. However, the increased ratio of linolenic acid-to-linoleic acid cannot explain the observed reduction in $\mathrm{CH}_{4}$ production with the hemp oil, as both hemp and raspberry oils had the same ratio. Wang et al. (2017) reported that the level of methanogenesis and the ratios of linoleic acid to linolenic acid in seed oils were not related; therefore, the reductions in $\mathrm{CH}_{4}$ production with the blueberry and hemp oils may be largely due to their bioactive compounds. The polyphenolic and antioxidant compounds in blueberry and hemp oils may have negative effects on microbial fermentation (McPartland, 1984; Khalifa et al., 2015). Hemp contains many classes of resinous compounds, such as terpenes, terpenols, cannabinoids and dihydrostilbenes. Cannabinoids have been reported to exhibit antimicrobial activity against bacteria and fungi (Klingeren and Ham, 1976; McPartland, 1984). Hemp oil also contains important terpenes, such as $\alpha$-pinene, $\beta$-pinene, limonene, $\alpha$-selinene, $\beta$-caryophyllene and $\beta$-humulene (Romano and Hazekamp, 2013). It was observed that the sesquiterpenes caryophyllene and humulene were only mildly inhibitory to methanogens. However, polar phenols, monoterpenes and terpenols have been reported to exert high methanogenic toxicity (Kortekaas et al., 1995). Blueberries also contain flavonoids and hydrolyzable tannins, such as quercetin and kaempferol, with a small amount of gallic acid, gallotannic, pyrogallol, caffeic acid, and catechin (Yi et al., 2006). Oskoueian et al. (2013) observed that flavonoids such as catechin and kaempferol decrease the rumen microbial population and that quercetin reduces the total populations of protozoa and methanogens in vi- 
tro. The derivates of hydrolyzable tannins, such as gallic acid, gallotannic acid and pyrogallol, have been reported to exert high methanogenic toxicity (Field and Lettinga, 1987). Furthermore, tannins are known to reduce the protozoal population (Bhatta et al., 2009). Flavonoids have been reported to serve as alternative $\mathrm{H}_{2}$ sinks during the degradation of their metabolites (Williamson and Clifford, 2010). For example, Becker et al. (2014) indicated that $1.0 \mathrm{~mol}$ catechin prevented the emission of $1.2 \mathrm{~mol} \mathrm{CH}_{4}$.

In the present experiment, $\mathrm{CH}_{4}$ production was not affected by the addition of corn, raspberry, pomegranate or black seed oils. A review by Beauchemin et al. (2008) estimated that $\mathrm{CH}_{4}$ production in ruminants is reduced by $5.6 \%$ for every $1 \%$ increase in added dietary lipid. Girón et al. (2016) observed that the addition of $40 \mathrm{~g} \mathrm{~kg}^{-1}$ of corn oil to the diet of dairy cows decreased $\mathrm{CH}_{4}$ production by $16 \%$. Maleki et al. (2016) reported a decrease in $\mathrm{CH}_{4}$ concentration when pomegranate oil was added to rumen cultures at $10 \mathrm{mg} 75 \mathrm{ml}^{-1}$. Sallam et al. (2009) also reported significant reductions in $\mathrm{CH}_{4}$ concentration when black seed extract was added to rumen cultures at $0.5,0.75$ and $1.0 \mathrm{ml}^{7} 75 \mathrm{ml}^{-1}$. In contrast, in Rusitec fermenter, the addition of 50 and $500 \mathrm{mg} \mathrm{L}^{-1}$ black seed oil to rumen cultures (forage-to-concentrate, 48:52) did not affect the protozoal count (Klevenhusen et al., 2015). The dietary lipid supplementation effects on rumen methanogenesis can vary by the composition of the basal diet. According to Patra (2013), the inhibitory effect of lipids on methanogenesis is more pronounced in ruminants fed concentratebased diets than in ruminants fed forage-based diets. Dong et al. (1997) found that the depressive effect of lipid supplementation on $\mathrm{CH}_{4}$ production was greater with a concentrate-based diet than with a hay diet. Hook et al. (2011) reported an altered methanogen community and diversity in high-concentrate feeding dairy cattle. Machmuller et al. (1998) found that dietary supplementation with sunflower seed reduced $\mathrm{CH}_{4}$ production up to $40 \%$ in a concentrate-based diet, whereas it decreased by $23 \%$ with a medium-concentrate diet. The forage-to-concentrate ratio in our basal diet (50:50) most likely weakened the oil's potential $\mathrm{CH}_{4}$-suppressing effects. However, the present study confirms that hemp and blueberry oil supplementation to ruminant diets can decrease $\mathrm{CH}_{4}$ production by $10-16 \%$ relative to that of the control. This result is similar to the results of a meta-analysis study by Patra (2013), who noted that lipid supplementation up to $60 \mathrm{~g} \mathrm{~kg}^{-1}$ of the diet (DM) can decrease $\mathrm{CH}_{4}$ emissions (up to $15 \%$ ) in cattle without a reduction of feed digestion and fermentation.

The results from the present study showed that, except for hemp oil and blueberry oil, the unconventional oils had no effects on rumen $\mathrm{CH}_{4}$ production. The addition of hemp and blueberry oils reduced $\mathrm{CH}_{4}$ production without negatively affecting rumen fermentation and total VFA concentration. The reductions in $\mathrm{CH}_{4}$ production observed with hemp and blueberry oils most likely resulted from their effects on methanogens. Although these two oils slightly affected rumen methane production, questions remain to be answered about the long-term effects of supplementation with these unconventional oils on rumen fermentation and the ability of rumen microbes to adapt to these oils or their active compounds. Additionally, further studies are needed to elucidate the mechanisms by which these different unconventional oils and/or their bioactive compounds affect rumen fermentation and the rumen microbial community. 


\title{
Resumen
}

\begin{abstract}
M. Embaby, M. Günal, y A. AbuGhazaleh. 2019. Efecto de los aceites no convencionales en la producción y fermentación in vitro de metano del rumen. Cien. Inv. Agr. 46(3): 276-285. . Los efectos de los aceites no convencionales altos en ácidos grasos poliinsaturados (PUFA) (mora, arándano, frambuesa, Granada, semilla negra y cáñamo) en la producción de rumen in vitro de fermentación y metano $\left(\mathrm{CH}_{4}\right)$ fueron examinados en experimentos de cultivo por lotes de tres 24-h. Los tratamientos en cada experimento consistían en control (sin suplemento de aceite), control más aceite de maíz, o control más dos de los aceites no convencionales. Se añadieron aceites a las culturas rumen en $500 \mathrm{mg} \mathrm{L}^{-1}$ (equivalente a $3,3 \mathrm{~g}$ aceite $\mathrm{kg}^{-1}$ de materia seca dietética (DM)). Después de 24 horas de incubación, la producción de $\mathrm{CH}_{4}$ no fue diferente entre el control y los tratamientos de aceite de maíz. De los seis aceites no convencionales probados, sólo los aceites de cáñamo y arándano redujeron la producción de $\mathrm{CH}_{4}$ en un 9-16\% en relación con los tratamientos de control y aceite de maíz. La degradabilidad de la materia seca y los ácidos grasos volátiles totales (VFA) no se vieron afectados por la adición de aceites de cáñamo y arándano. A excepción de una reducción en la concentración de acetato con el aceite de frambuesa, y un aumento en la concentración de valerato con el aceite de Granada, todos los aceites no convencionales probados no tuvieron efectos sobre la fermentación y el perfil de VFA en relación con el control. En conclusión, nuestros resultados mostraron que los aceites de cáñamo y arándano eran moderadamente efectivos para reducir la formación del rumen $\mathrm{CH}_{4}$ sin comprometer la fermentación y digestibilidad del rumen.
\end{abstract}

Palabras clave: Aceite de arándano, aceite de cáñamo, aceite de frambuesa, cultura rumen, metano.

\section{References}

AOAC. Association of Official Analytical Chemists. 2000. Official Methods of Analysis (17th ed.). Inc. Washington, D.C. USA.

Beauchemin, K.A., M. Kreuzer, F. O'mara, and T.A. McAllister. 2008. Nutritional management for enteric methane abatement: a review. Aust. J. Exp. Agric. 48(2):21-27.

Becker, P.M., P.G. Van Wikselaar, M.C.R.R. Franssen, C.H. De Vos, R.D. Hall, and J. Beekwilder. 2014. Evidence for a hydrogen-sink mechanism of $(+)$ catechin mediated emission reduction of the ruminant greenhouse gas methane. Metabolomics 10:179-189.

Bhatta, R., Y. Uyeno, K. Tajima, A. Takenaka, Y. Yabumoto, I. Nonaka, O. Enishi, and M. Kurihara. 2009. Difference in the nature of tannins on in vitro ruminal methane and volatile fatty acid production and on methanogenic archaea and protozoal populations. J. Dairy Sci. 92:5512-5522.
Chilliard, Y., C. Martin, J. Rouel, and M. Doreau. 2009. Milk fatty acids in dairy cows fed whole crude linseed, extruded linseed, or linseed oil, and their relationship with methane output. J. Dairy Sci. 92(10):5199-5211.

Cotta, M.A., and J.B. Russell. 1982. Effects of peptides and amino acids on efficiency of rumen bacterial protein synthesis in continuous culture. J. Dairy Sci. 65:226-234.

Czerkawski, J.W., K.L. Blaxter, and F.W. Wainman. 1966. The metabolism of oleic, linoleic and linolenic acids by sheep with reference to their effects on methane production. Br. J. Nutr. 20:349-362.

Dahham, S.S., M.N. Ali, H. Tabassum, and M. Khan. 2010. Studies on antibacterial and antifungal activity of pomegranate (Punica granatum L.). Am-Eurasian J. Agric. Environ. Sci. 9:273-281.

Dong, Y., H.D. Bae, T.A. McAllister, G.W. Mathison, and K.J. Cheng. 1997. Lipid induced de- 
pression of methane production and digestibility in the artificial rumen system (Rusitec). Can. J. Anim. Sci. 77:269-278.

El-Sherbiny, M., A. Cieslak, E. Pers-Kamczyc, J. Szczechowiak, D. Kowalczyk, and M. Szumacher-Strabel. 2016. A nanoemulsified form of oil blends positively affects the fatty acid proportion in ruminal batch cultures. J. Dairy Sci. 99(1):399-407.

Field, J.A., and G. Lettinga.1987. The methanogenic toxicity and anaerobic degradability of a hydrolysable tannin. Water Res. 21:367-374.

Garcia-Gonzalez, R., S. Lopez, M. Fernandez, R. Bodas, and J.S. Gonzalez. 2008. Screening the activity of plants and spices for decreasing ruminal methane production in vitro. Anim. Feed. Sci. Technol. 147:36-52.

Girón, J.E.P., M.L.P. Restrepo, and J.E.C. Fornaguera. 2016. Supplementation with corn oil and palm kernel oil to grazing cows: ruminal fermentation, milk yield, and fatty acid profile. Rev. Bras. Zootecn. 45(11):693-703.

Goering, H.K., and P.J. Van Soest. 1970. Forage fiber analysis (Apparatus, reagents, procedures, and some applications). Agriculture Handbook No. 379, ARS-USDA, Washington, USA. 20p.

Hervas, G., P. Luna, A.R. Mantecon, N. Castanares, M.A. de la Fuente, M. Juarez, and P. Frutos. 2008. Effect of diet supplementation with sunflower oil on milk production, fatty acid profile and ruminal fermentation in lactating dairy ewes. J. Dairy Res. 75:399-405.

Hook, S.E., M.A. Steele, K.S. Northwood, A.G. Wright, and B.W. McBride. 2011. Impact of high-concentrate feeding and low ruminal $\mathrm{pH}$ on methanogens and protozoa in the rumen of dairy cows. Microb. Ecol. 62:94-105.

Ivan, M., H.V. Petit, J. Chiquette, and A.D. Wright. 2013. Rumen fermentation and microbial population in lactating dairy cows receiving diets containing oilseeds rich in C-18 fatty acids. Br. J. Nutr. 109:1211-1218.

Jenkins, T.C. 1987. Effect of fats and fatty acid combinations on ruminal fermentation in semi-continuous in vitro cultures. J. Anim. Sci. 64:15261532.
Khalifa, H.O., M. Kamimoto, T. Shimamoto, and T. Shimamoto. 2015. Antimicrobial effects of blueberry, raspberry, and strawberry aqueous extracts and their effects on virulence gene expression in Vibrio cholerae. Phytother. Res. 29(11):1791-1797.

Klevenhusen, F., K. Deckardt, Ö. Sizmaz, S. Wimmer, A. Muro-Reyes, R. Khiaosa-Ard, R. Chizzola, and Q. Zebeli. 2015. Effects of black seed oil and Ferula elaeochytris supplementation on ruminal fermentation as tested in vitro with the rumen simulation technique (Rusitec). Anim. Prod. Sci. 55(6):736-744.

Klingeren, B., and M.T. Ham. 1976. Antibacterial activity of delta-9-tetrahydrocannabinol and cannabidiol. Anton. Leeuwenhoek 42:9-12.

Kortekaas, S., M. Soto, T. Vicent, J.A. Field, and G. Lettinga. 1995. Contribution of extractives to methanogenic toxicity of hemp black liquor. J. Ferment. Bioeng. 80(4):383-388.

Lillis, L., B. Boots, D.A. Kenny, K. Petrie, T.M. Boland, N. Clipson, and E.M. Doyle. 2011. The effect of dietary concentrate and soya oil inclusion on microbial diversity in the rumen of cattle. J. Appl. Microbiol. 111:1426-1435.

Machmüller, A., D.A. Ossowski, M. Wanner, and M. Kreuzer. 1998. Potential of various fatty feeds to reduce methane release from rumen fermentation in vitro (Rusitec). Anim. Feed Sci. Technol. 71:117-130.

Maleki, E., G.Y. Meng, M.F. Jahromi, R. Jorfi, A. Khoddami, and M. Ebrahimi. 2016. Pomegranate seed oil rich in conjugated linolenic acids reduces in vitro methane production. S. Afr. J. Anim. Sci. 46(3):325-335.

McPartland, J.M. 1984. Pathogenicity of Phomopsis ganjae on Cannabis sativa and the fungistatic effect of cannabinoids produced by the host. Mycopathologia. 87:149-153.

Oskoueian, E., N. Abdullah, and A. Oskoueian. 2013. Effects of flavonoids on rumen fermentation activity, methane production, and microbial population. Biomed. Res. Int. 2013.

Parry, J., and L. Yu. 2004. Fatty acid content and antioxidant properties of cold-pressed black raspberry seed oil and meal. J. Food Sci. 69:189-193.

Patra, A.K. 2013. The effect of dietary fats on meth- 
ane emissions, and its other effects on digestibility, rumen fermentation and lactation performance in cattle: A meta-analysis. Livest. Sci. 155:244-254.

Popova, M., C. Martin, M. Eugène, M.M. Mialon, M. Doreau, and D.P. Morgavi. 2011. Effect of fibre- and starch-rich finishing diets on methanogenic archaea diversity and activity in the rumen of feedlot bulls. Anim. Feed Sci. Technol. 166-167:113-121.

Prins, R.A., C.J. Van Nevel, D.I. Demeyer. 1972. Pure culture studies of inhibitors for methanogenic bacteria. Anton. Leeuwenhoek 38:281-287.

Ramin, M., and P. Huhtanen. 2013. Development of equations for predicting methane emissions from ruminants. J. Dairy Sci. 96:2476-2493.

Romano, L. L., A. Hazekamp. 2013. Cannabis oil: chemical evaluation of an upcoming cannabisbased medicine. Cannabinoids, 1(1):1-11.

Roy, A., G.P. Mandal, and A.K. Patra. 2017. Effects of different vegetable oils on rumen fermentation and conjugated linoleic acid concentration in vitro. Vet. World. 10(1):11-16.

Salem, H.B., R. Krzeminski, A. Ferlay, and M. Doreau. 1993. Effect of lipid supply on in vivo digestion in cows: Comparison of hay and corn silage diets. Can. J. Anim. Sci. 73:547-557.

Sallam, S.M.A., I.C.S. Bueno, P. Brigide, P.B. Godoy, D.M.S.S. Vitti, and A.L. Abdalla. 2009. Investigation of potential new opportunities for plant extracts on rumen microbial fermentation in vitro. In: T.G. Papachristou, Z.M. Parissi, H.
Ben Salem, P. Morand-Fehr, (Eds). Nutritional and foraging ecology of sheep and goats. Zaragoza : CIHEAM / FAO / NAGREF, 2009. (Options Méditerranéennes : Série A. Séminaires Méditerranéens; n. 85). p. 255-260.

Wang, S., M. Kreuzer, U. Braun, and A. Schwarm. 2017. Effect of unconventional oilseeds (safflower, poppy, hemp, camelina) on in vitro ruminal methane production and fermentation. J. Sci. Food Agric. 97(11):3864-3870.

Whitney, M.B., B.W. Hess, L.A. Burgwald-Balstad, J.L. Sayer, C.M. Tsopito, C.T. Talbott, and D.M. Hallford. 2000. Effects of supplemental soybean oil level on in vitro digestion and performance of prepubertal beef heifers. J. Anim. Sci. 78(3):504-514.

Williamson, G., and M.N. Clifford. 2010. Colonic metabolites of berry polyphenols: the missing link to biological activity? Br. J. Nutr. 104:S48S66.

Yi, W., C.C. Akoh, J. Fischer, and G. Krewer. 2006. Effects of phenolic compounds in blueberries and muscadine grapes on $\mathrm{HepG} 2$ cell viability and apoptosis. Food Res. Int. 39:628-638.

Zhang, C.M., Y.Q. Guo, Z.P. Yuan, Y.M. Wu, J.K. Wang, J.X. Liu, and W.Y. Zhu. 2008. Effect of octadeca carbon fatty acids on microbial fermentation, methanogenesis and microbial flora in vitro. Anim. Feed Sci. Technol. 146:259-269. 